\title{
Recent advances in treating oesophageal cancer [version 1;
}

\section{peer review: 3 approved]}

\section{Kazuto Harada(101,2, Jane E. Rogers³, Masaaki Iwatsuki1,2, Kohei Yamashita², Hideo Baba², Jaffer A. Ajani ${ }^{1}$}

\author{
${ }^{1}$ Department of Gastrointestinal Medical Oncology, University of Texas M. D. Anderson Cancer Center, 1515 Holcombe Blvd, \\ Houston, TX, 77030, USA \\ ${ }^{2}$ Department of Gastroenterological Surgery, Graduate School of Medical Science, Kumamoto University, 1-1-1 Honjo, Kumamoto, \\ 860-8556, Japan \\ ${ }^{3}$ Department of Pharmacy Clinical Program, University of Texas M. D. Anderson Cancer Center, 1515 Holcombe Blvd, Houston, TX, \\ 77030, USA
}

\section{V1 First published: 01 Oct 2020, 9(Faculty Rev):1189 \\ https://doi.org/10.12688/f1000research.22926.1 \\ Latest published: 01 Oct 2020, 9(Faculty Rev):1189 \\ https://doi.org/10.12688/f1000research.22926.1}

\section{Abstract}

Esophageal cancer (EC) is an aggressive malignancy with an increasing incidence and a poor prognosis. EC is histologically divided into two major categories: adenocarcinoma (EAC) and squamous cell carcinoma (ESCC). EAC and ESCC are molecularly different and therefore treatments should reflect the respective histological subtype. Combined modality therapy is needed for localized EC. When EC is advanced (stage 4), systemic therapy is the mainstay treatment for palliation. For localized EC, several strategies are considered standard, and more trials are necessary to determine a unified and more effective approach. The management for advanced EC is slowly evolving as immunotherapy is showing some promise for ESCC, but more data from ongoing studies are anticipated. Treatment advances will be based on high-definition genomic investigation of individual tumors. Herein, we review the contemporary trends in diagnosing and treating EAC and ESCC.

\section{Keywords}

esophageal cancer, esophageal adenocarcinoma, esophageal squamous cell carcinoma

\section{Open Peer Review}

\section{Approval Status}

1 2 3

version 1

01 Oct 2020

Faculty Reviews are review articles written by the prestigious Members of Faculty Opinions. The articles are commissioned and peer reviewed before publication to ensure that the final, published version is comprehensive and accessible. The reviewers who approved the final version are listed with their names and affiliations.

1. Rebecca K. S. Wong, University of Toronto, Toronto, Canada

2. Daniela Molena, Memorial Sloan Kettering Cancer Center, New York, USA

3. James P. Dolan, Oregon Health and Science University, Portland, USA

Any comments on the article can be found at the end of the article. 
Corresponding author: Jaffer A. Ajani (jajani@mdanderson.org)

Author roles: Harada K: Writing - Original Draft Preparation, Writing - Review \& Editing; Rogers JE: Writing - Review \& Editing; Iwatsuki M: Writing - Review \& Editing; Yamashita K: Writing - Review \& Editing; Baba H: Writing - Review \& Editing; Ajani JA: Supervision, Writing - Review \& Editing

Competing interests: No competing interests were disclosed.

Grant information: This work was supported by generous grants from the Caporella, Dallas, Sultan, Park, Smith, Frazier, Oaks, Vanstekelenberg, Planjery, and Cantu families, as well as from the Schecter Private Foundation, Rivercreek Foundation, Kevin Fund, Myer Fund, Dio Fund, Milrod Fund, and The University of Texas MD Anderson Cancer Center (Houston, Texas, USA) multidisciplinary grant program. This research was also supported in part by National Cancer Institute grants CA129906, CA127672, CA138671, and CA172741; by Department of Defense grants CA150334 and CA162445 (J.A.A.); and by a grant from the Japan Society for the Promotion of Science Overseas Research Fellowships and Program for Advancing Strategic International Networks to Accelerate the Circulation of Talented Researchers (K.H.).

The funders had no role in study design, data collection and analysis, decision to publish, or preparation of the manuscript.

Copyright: @ 2020 Harada $\mathrm{K}$ et al. This is an open access article distributed under the terms of the Creative Commons Attribution License, which permits unrestricted use, distribution, and reproduction in any medium, provided the original work is properly cited.

How to cite this article: Harada K, Rogers JE, Iwatsuki M et al. Recent advances in treating oesophageal cancer [version 1; peer review: 3 approved] F1000Research 2020, 9(Faculty Rev):1189 https://doi.org/10.12688/f1000research.22926.1

First published: 01 Oct 2020, 9(Faculty Rev):1189 https://doi.org/10.12688/f1000research.22926.1 


\section{Introduction}

Esophageal cancer (EC) is the eleventh most common cause of cancer worldwide (473,000 cases) and the sixth most common cause of cancer-related mortality $(436,000 \text { deaths })^{1}$. ECs are classified into two common histologic subtypes: adenocarcinoma (EAC) and squamous cell carcinoma (ESCC). ESCC is prevalent in Eastern Europe and Asia (endemic areas) but has become less common in Western countries. EAC is prevalent in North America and Western Europe. Tobacco and alcohol consumption and ALDH2 heterozygosity are the major risk factors for $\mathrm{ESCC}^{2,3}$, while obesity and Barrett's esophagus are the major risk factors for $\mathrm{EAC}^{4,5}$. EAC and ESCC are molecularly different, thus their treatments should be different. However, there is still considerable overlap between EAC and ESCC treatment. Thus, the need to differentiate treatment based on histology should be one of the goals of future research ${ }^{6}$.

\section{Treatment for resectable EAC}

\section{Endoscopic resection}

The European Society of Gastrointestinal Endoscopy and The National Comprehensive Cancer Network (NCCN) guidelines have recommended that an endoscopic resection is indicated for patients with T1a or superficial pT1b tumors that are $\leq 3 \mathrm{~cm}$ in tumor diameter, do not have clear lymphovascular invasion (LVI), and do not have poorly differentiated histology ${ }^{7,8}$. A recent Japanese study has provided a similar indication ${ }^{9,10}$. However, long-term outcomes after endoscopic resection remain controversial for pT1b tumors. Endoscopic submucosal dissection (ESD) is preferred over a piecemeal resection for accurate pathological evaluation. Endoscopic mucosal resection (EMR) has the limitation of size for an en bloc resection, generally tumors of 1.5 to $2 \mathrm{~cm}$ in diameter. An ESD requires higher endoscopic skill, but it enables en bloc resection regardless of the tumor size. A small randomized study of high-grade dysplasia or early EAC in which tumor size was $3 \mathrm{~cm}$ or smaller in diameter showed that ESD provided higher R0 and curative resection rates than $\mathrm{EMR}^{11}$. However, it remains unclear whether ESD improves long-term outcomes.

\section{Combined modality therapy}

Surgery is the most effective strategy to cure localized EAC in early stage disease. However, surgery alone is usually inadequate in advanced cases. Preoperative chemoradiation or perioperative chemotherapy are currently utilized as an adjunct to surgery. The choice of preoperative strategy is largely based on practice preferences.

The CROSS trial provided evidence for the efficacy of preoperative chemoradiation followed by surgery over surgery alone ${ }^{12}$. EC patients were randomly assigned to one of two groups: preoperative chemoradiation $(\mathrm{n}=180)$ and surgery alone ( $\mathrm{n}=188$ ). Patients were highly selected. The overall survival (OS) for the preoperative chemoradiation group was significantly longer than that for the surgery alone group (median OS 48.6 months vs. 24.0 months; hazard ratio [HR] 0.68 ; $95 \%$ confidence interval $[\mathrm{CI}] 0.53-0.88 ; P=0.003)^{13}$. Another randomized trial (CALGB 9781) assessed only 56 patients but also showed benefit for preoperative chemoradiation ${ }^{14}$. However, the benefit from preoperative chemoradiation for patients with EAC with stage I/II EC remains debatable based on the result of the FFCD 9901 trial, which showed similar R0 resection rate and no OS benefit but increased postoperative mortality ${ }^{15}$.

The MAGIC trial was designed to investigate chemotherapy in gastric cancer. The study cohort also contained a proportion of patients with gastroesophageal and proximal gastric cancers. This study found that the perioperative chemotherapy group (three preoperative and three postoperative cycles of epirubicin, cisplatin, and fluorouracil [ECF]) had a favorable OS compared with surgery alone (5-year rate: $36 \%$ vs. $23 \%$; HR 0.75 ; 95\% CI $0.60-0.93 ; P=0.009)^{16}$. Following this trial, especially in Europe, the MAGIC regimen was the preferred standard, but the use of epirubicin had been controversial ${ }^{17}$. Recently, the FLOT4 trial showed survival benefit of 5-fluorouracil, leucovorin, oxaliplatin, and docetaxel (FLOT) over $\mathrm{ECF}^{18}$. A total of 716 patients were randomized to receive FLOT $(n=356)$ or ECF $(n=360)$. Median OS was significantly longer in the FLOT group compared with the ECF group (median OS 50 months vs. 35 months; HR 0.77; 95\% CI 0.63-0.94). Although the reported rate of pathological complete response (pCR) was higher in the FLOT group than in the ECF group (16\% vs. $6 \%$; $P=0.02)$, this conclusion remains unclear ${ }^{18}$. Adverse events were more frequent in the FLOT group. The most notable adverse effect differences were the incidence of grade 3 or 4 infections ( $18 \%$ vs. $9 \%$ ), neutropenia ( $51 \%$ vs. $39 \%)$, diarrhea (10\% vs. $4 \%$ ), and neuropathy (7\% vs. $2 \%$ ). The number of patients with severe adverse events, including those occurring during the hospital stay for surgery, were similar in the two groups: $27 \%$ in the ECF group and $27 \%$ in the FLOT group. Given the toxicity profile, the FLOT regimen should be reserved for patients with a good performance status. The difficulty of perioperative chemotherapy, particularly in completion of postoperative chemotherapy, remains an issue, as seen by the FLOT4 trial. FLOT4 showed that, even in relatively healthy patients enrolled in a clinical trial, the number who completed all allocated cycles was low: $37 \%$ in the ECF group and $46 \%$ in the FLOT group. Combination therapy with two cytotoxic drugs, for example oxaliplatin plus 5-fluorouracil (FOLFOX), is considered a perioperative recommended regimen for patients who have good to moderate performance status ${ }^{19-22}$. Overall, the projected 5-year survival rate of $40-45 \%$ emphasizes a need for significant improvement in the treatment of these cancers.

$\mathrm{R} 0$ resection is one of the most important factors for selecting surgery. R0 resection rate is worse in Siewert I or primary EAC than gastric cancer, even after preoperative chemotherapy ${ }^{23}$. This result suggests that local control by adding radiation could be needed for primary EAC. It should be noted that the FLOT4 trial included many patients with gastric cancer.

\section{Systemic therapy for metastatic EAC}

First-line systemic therapy

Systemic therapy for metastatic EAC has been based on a study designed together with gastric adenocarcinomas. Fluoropyrimidines (5-fluorouracil or capecitabine) combined with either oxaliplatin or cisplatin has been the global standard 
therapy for decades ${ }^{24}$. For patients with HER2-positive EAC, adding trastuzumab to fluoropyrimidine plus platinum is recommended based on the ToGA trial ${ }^{25}$. Other molecular targeted drugs were assessed, but no additional targeted agents were found to be beneficial for EAC as the first-line therapy at this point in time ${ }^{24}$.

\section{Second-line or subsequent systemic therapy}

Ramucirumab plus paclitaxel is the preferred regimen for second-line therapy based on the RAINBOW study ${ }^{26}$. Ramucirumab monotherapy is an option for patients who are not candidates for combination therapy with paclitaxel ${ }^{27}$. Single administration of chemotherapeutic agents, such as irinotecan and taxanes, significantly improves OS compared with best supportive care $^{28}$.

Assessment of microsatellite instability (MSI) status and programmed death ligand 1 (PD-L1) expression is recommended. However, MSI tumors are rare in EC, and PD-1 or PD-L1 blockade is marginally effective in EAC. Recently, based on several trials, such as KEYNOTE-016, KEYNOTE-164, KEYNOTE-012, KEYNOTE-028, and KEYNOTE-158, pembrolizumab has been approved as a second-line regimen for patients with MSI-high/deficient mismatch repair (MMR) solid tumors, regardless of the tumor type. Le et al. reported that objective radiographic response (ORR) was observed in 53\% of patients, and complete response was achieved in $21 \%$ of patients with deficient MMR tumor ${ }^{29}$. The KEYNOTE-059 study showed that ORR was as high as $57 \%$ in patients with MSI-high tumors, which is significantly higher than $9 \%$ in the case of microsatellite stable tumors ${ }^{30}$.

In the United States in 2017, pembrolizumab was approved for advanced EAC patients with PD-L1-positive tumors (combined positive score [CPS] >1) who have cancer progression after two or more prior therapies. In the KEYNOTE-059 trial, 259 patients with gastric or esophagogastric junction (EGJ) adenocarcinoma who have progressed after two or more prior therapies were assessed. Pembrolizumab monotherapy showed that ORR was higher in patients with PD-L1-positive disease than in those with PD-L1-negative disease $(15.5 \% \text { vs. } 6.4 \%)^{30}$.

ATTRACTION-2 evaluated the efficacy of nivolumab in patients with advanced gastric or EGJ adenocarcinoma who underwent at least two previous chemotherapy regimens. Here, 493 patients were randomly assigned to receive nivolumab $(\mathrm{n}=330)$ or placebo $(\mathrm{n}=163)^{31}$. Median OS was 5.26 months in the nivolumab group and 4.14 months in the placebo group (HR 0.63; 95\% CI 0.51-0.78; $P<0.001$ ). Moreover, the survival benefit with nivolumab was independent of PD-L1 expression. Thus, nivolumab is accepted as third-line therapy regardless of PD-L1 expression in Japan.

Recently, the phase III TAGS trial evaluated the efficacy of TAS-102, an orally administered combination of a thymidinebased nucleic acid analogue, trifluridine, and a thymidine phosphorylase inhibitor, tipiracil hydrochloride, in metastatic gastric and EGJ adenocarcinoma as third-line therapy ${ }^{32}$. A total of 507 patients were randomly assigned to the trifluridine/tipiracil group $(n=337)$ and to the placebo group $(n=170)$. Median OS was 5.7 months in the trifluridine/tipiracil group and 3.6 months in the placebo group (HR 0.69 ; 95\% CI $0.56-0.85$; $P=0.00058)^{32}$. Thus, TAS-102 was approved as an option for third-line therapy. However, only a select population might be suitable for TAS-102 because of the lack of response rate.

\section{Treatment for resectable ESCC}

\section{Endoscopic resection}

The NCCN guidelines state that endoscopic resection is adapted for early stage disease (pTis, pT1a, selected superficial pT1b without LVI and favorable histology) ${ }^{33}$. Japanese esophageal cancer guidelines recommend endoscopic resection for only T1a ESCC tumors ${ }^{34,35}$. Lymph node metastases of pT1a-epithelium (EP)/lamina propria mucosae (LPM) is very rare, but pT1a- muscularis mucosae (MM) can develop metastases, in some cases in $10 \%$ of patients ${ }^{36}$. T1b tumors are generally not considered appropriate for endoscopic treatment in Japan ${ }^{37}$. Recently, the JapanClinical Oncology Group (JCOG) 0508 trial suggested that endoscopic resection in combination with chemoradiation is efficacious for cT1bN0M0 ESCC as an esophagus-preserving treatment ${ }^{38}$.

\section{Combined modality therapy}

ESCC is very sensitive to chemoradiation, and this results in higher rates of complete tumor regression and better local tumor control, but it is unclear if a better survival is achieved than in EAC patients ${ }^{39}$. Thus, preoperative chemoradiation is globally recommended as standard of care for treating ESCC. Moreover, definitive chemoradiation is an acceptable option for treating ESCC. The FFCD 9102 trial found that, for ESCC patients who respond to chemoradiation, adding surgery had no survival benefit compared with the continuation of additional chemoradiation $^{40}$.

Preoperative chemotherapy is also an option for ESCC. The OEO2 trial showed that the perioperative chemotherapy (two cycles of FP; cisplatin and fluorouracil) group had a favorable OS compared with the surgery alone group (5-year OS rate: $23 \%$ vs. $17 \%$; HR $0.84 ; 95 \%$ CI $0.72-0.98 ; P=0.03$ ), but the rate of ESCC patients in this study was only $34 \%{ }^{20,21}$. The JCOG9907 trial compared preoperative and postoperative chemotherapy (two cycles of FP) for stage II or III ESCC ${ }^{41}$. OS in the preoperative group was better than in the postoperative chemotherapy group, but a limitation for this protocol was that patients with $\mathrm{pNO}$ in the postoperative chemotherapy group did not undergo chemotherapy.

\section{Systemic therapy for advanced ESCC}

\section{First-line systemic therapy}

As with EAC, fluoropyrimidine (5-fluorouracil or capecitabine) combined with either oxaliplatin or cisplatin has been the most commonly used first-line regimen for advanced $\mathrm{ESCC}^{42}$. No targeted therapy has proven effective in this disease to date ${ }^{43}$.

\section{Second-line or subsequent systemic therapy}

Single-agent chemotherapy with taxanes or irinotecan is an option for second-line therapy ${ }^{44-46}$. However, results with second-line chemotherapy in ESCC are inferior to those in EAC. 
An immune checkpoint inhibitor has been approved as secondline or subsequent therapy for advanced ESCC. Pembrolizumab has also been accepted as a second-line therapy for patients with advanced ESSC with PD-L1 expression levels by CPS of $>10$. The phase III KEYNOTE-181 trial compared pembrolizumab versus investigator's choice chemotherapy (docetaxel, paclitaxel, or irinotecan) as second-line therapy in 628 patients with advanced $\mathrm{EC}^{47}$. Pembrolizumab significantly improved median OS (9.3 months vs. 6.7 months; HR 0.69; 95\% CI 0.52-0.93; $P=0.0074)$ and 12-month OS rates (43\% vs. 20\%) compared with chemotherapy in patients whose tumors had a PD-L1 CPS $>10$.

Recently, nivolumab has been accepted as a second-line therapy for ESCC in Japan based on ATTRACTION-3 outcome ${ }^{48}$. A total of 419 previously treated patients with ESCC were randomly assigned to nivolumab $(\mathrm{n}=210)$ and chemotherapy $(n=209)$. OS was significantly improved in nivolumab; median OS in the nivolumab and chemotherapy group was 10.9 months and 8.4 months, respectively (HR $0.77 ; 95 \%$ CI $0.62-0.96$; $P=0.019)^{48}$. In the KEYNOTE-180 trial, 121 patients with EC (63 ESCC and 58 EAC) who progressed after two or more prior therapies were assessed. Pembrolizumab monotherapy showed that ORR was $14.3 \%$ (95\% CI 6.7-25.4\%) in patients with ESCC and 5.2\% (95\% CI 1.1-14.4\%) in patients with EAC $^{49}$. ORR was higher in patients with PD-L1-positive tumor $(13.8 \% \text { vs. } 6.3 \%)^{49}$. These results demonstrated the efficacy and tolerability of pembrolizumab as a third-line or subsequent therapy option in patients with heavily pretreated ESSC with high PD-L1 expression.

\section{Future perspective}

\section{Preoperative chemoradiation or chemotherapy}

Preoperative chemotherapy and preoperative chemoradiation strategies remain popular in different regions of the globe. A recent meta-analysis using network meta-analyses showed better OS in preoperative chemoradiation than in preoperative chemotherapy (HR 0.83; 95\% CI $0.70-0.96)^{50}$. A retrospective review from our institution showed that preoperative chemoradiation was associated with a longer OS and a higher pCR rate in $\mathrm{EAC}^{51}$. To date, three randomized trials have compared preoperative chemoradiotherapy and chemotherapy, but none could reach a definitive conclusion ${ }^{52-54}$. The following studies are comparing preoperative chemoradiation and chemotherapy: the PROTECT study (NCT02359968), Neo-AEGIS trial (NCT01726452), and NEOSCOPE trial (NCT01843829). In Japan, a three-arm phase III trial (JCOG1109) is comparing preoperative FP versus preoperative DCF versus preoperative chemoradiation for $\mathrm{ESCC}^{55}$. These ongoing trials may provide considerable information on treatment options in the future.

\section{Personalized therapy for esophagus preservation}

Approximately $23 \%$ of patients with EAC and $49 \%$ of patients with ESCC achieve a pCR after preoperative chemoradiation ${ }^{12}$. However, in other datasets, pCR rates are no better than $20 \%$. One future hope is to avoid esophagectomy in select patients who are destined to achieve a pCR. However, a clinically implementable strategy to achieve this is currently lacking.
In EAC, we have reported that one positron emission tomographic (PET) parameter, total lesion glycolysis, could help to identify a population who can be cured after definitive chemoradiation $^{56}$. In addition, we reported that PET responses might predict survival and pathological response for chemoradiation $^{57}$. Thus, a strategy of selective surgery for remnant tumor might contribute to preserving the esophagus, but it still remains a challenge ${ }^{58}$. Accurate detection of residual tumor is difficult. The preSANO trial assessed optimal clinical response evaluation. Here, it was concluded that endoscopic ultrasonography with bite-on-bite biopsies and fine-needle aspiration of suspicious lymph nodes were suitable for the detection of locoregional residual disease (clinically false negative cases $10 \%$ in tumor regression grade 3 or 4) and PET-CT can be used for the detection of interval metastases ${ }^{59}$. Selective surgery by active surveillance is currently being assessed in the SANO trial ${ }^{60}$.

Because ESCC is more responsive to chemoradiation than EAC, preserving a patient's esophagus may be more feasible. The JCOG0502 trial compared survival for definitive chemoradiation and esophagectomy in stage I ESCC and demonstrated that the survival of definitive chemoradiation was non-inferior against that of an esophagectomy ${ }^{61}$. However, in the JCOG0502 trial, salvage esophagectomy was performed in 21 of 159 patients (13.2\%) in the chemoradiation group, and it should be noted that morbidity following salvage esophagectomy is high. A retrospective review from our institution showed that major postoperative complications after salvage esophagectomy frequently occurred in $71.4 \%$. The JCOG1406-A trial compared two Japanese trials conducted in the same era: JCOG9906, which evaluated definitive chemoradiation, and JCOG9907, which evaluated preoperative chemotherapy followed by esophagectomy for clinical stage II/III ESCC ${ }^{63}$. Although it is not a direct comparison, OS was better in the preoperative chemotherapy followed by esophagectomy group than in the definitive chemoradiation group (HR 1.72; 95\% CI 1.19-2.50) ${ }^{63}$. These data suggest that esophagectomy might be superior to definitive chemoradiation for clinical stage II/III ESCC, but a head-tohead comparison is lacking.

\section{Molecular biology}

TCGA reported an integrated genomic landscape in EAC and $\mathrm{ESCC}^{6,64}$. However, there are few studies assessing the association of genomic subtype and therapeutic response. We sequenced the whole exome and transcriptome of peritoneal metastatic cells and demonstrated distinct genomic alterations compared with primary tumor cells, suggesting that treatment strategy should be based on not only the cancer type but also the metastatic site ${ }^{65}$. Recently, liquid biopsy, such as circulating tumor cells, cell-free DNA, and exosomes, has the potential to predict early treatment response or identify intratumoral heterogeneity ${ }^{66-68}$. Further studies and clinical applications are expected. Therefore, in-depth study of the tumor's biology is warranted and may contribute to personalized therapy.

\section{Conclusion}

We have described the current understanding of the treatment options for EAC and ESCC. Combined modality therapy is 
needed for resectable EC. Head-to-head comparisons of preoperative chemotherapy and chemoradiation are warranted. The management for advanced EC has been evolving partly owing to the use of immune checkpoint inhibitors. The future challenge is to identify molecular targets based on tumor profiling.
Author contributions

$\mathrm{KH}$, JR, and JA conceived the review. KH prepared the first draft of the manuscript. All authors contributed to the preparation of the manuscript. All authors were involved in the revision of the draft manuscript and have agreed to the final content.
1. Global Burden of Disease Cancer Collaboration, Fitzmaurice C, Abate D, et al.: Global, Regional, and National Cancer Incidence, Mortality, Years of Life Lost, Years Lived With Disability, and Disability-Adjusted Life-Years for 29 Cancer Groups, 1990 to 2017: A Systematic Analysis for the Global Burden of Disease Study. JAMA Oncol. 2019; 5(12): 1749-1768. PubMed Abstract | Publisher Full Text | Free Full Text | Faculty Opinions Recommendation

2. Lewis SJ, Smith GD: Alcohol, ALDH2, and esophageal cancer: A metaanalysis which illustrates the potentials and limitations of a Mendelian randomization approach. Cancer Epidemiol Biomarkers Prev. 2005; 14(8): 1967-71.

PubMed Abstract | Publisher Full Text

3. Freedman ND, Abnet CC, Leitzmann MF, et al.: A Prospective Study of Tobacco, Alcohol, and the Risk of Esophageal and Gastric Cancer Subtypes. Am J Epidemiol. 2007; 165(12): 1424-33. PubMed Abstract | Publisher Full Text

4. Turati F, Tramacere I, La Vecchia C, et al:: A meta-analysis of body mass index and esophageal and gastric cardia adenocarcinoma. Ann Oncol. 2013; 24(3): 609-17.

PubMed Abstract | Publisher Full Text | Faculty Opinions Recommendation

5. Huid-Jensen F, Pedersen L, Drewes AM, et al.: Incidence of Adenocarcinoma among Patients with Barrett's Esophagus. N Engl J Med. 2011; 365(15): 1375-83.

PubMed Abstract | Publisher Full Text | Faculty Opinions Recommendation

6. Cancer Genome Atlas Research Network; Analysis Working Group: Asan University; BC Cancer Agency: Integrated genomic characterization of oesophageal carcinoma. Nature. 2017; 541(7636): 169-75.

PubMed Abstract | Publisher Full Text | Free Full Text |

Faculty Opinions Recommendation

7. Pimentel-Nunes P, Dinis-Ribeiro M, Ponchon T, et al.: Endoscopic submucosal dissection: European Society of Gastrointestinal Endoscopy (ESGE) Guideline. Endoscopy. 2015; 47(9): 829-54.

PubMed Abstract | Publisher Full Text

8. Ajani JA, D'Amico TA, Almhanna K, et al.: Esophageal and Esophagogastric Junction Cancers, Version 1.2015. J Natl Compr Canc Netw. 2015; 13(2): 194-227.

PubMed Abstract | Publisher Full Text

9. Aabe S, Ishihara R, Takahashi $\mathrm{H}$, et al.: Long-term outcomes of endoscopic resection and metachronous cancer after endoscopic resection for adenocarcinoma of the esophagogastric junction in Japan. Gastrointest Endosc. 2019; 89(6): 1120-8.

PubMed Abstract | Publisher Full Text | Faculty Opinions Recommendation

10. Ishihara $\mathrm{R}$, Oyama $\mathrm{T}$, Abe $\mathrm{S}$, et al.: Risk of metastasis in adenocarcinoma of the esophagus: A multicenter retrospective study in a Japanese population. J Gastroenterol. 2017; 52(7): 800-808. PubMed Abstract | Publisher Full Text

11. Terheggen $\mathrm{G}$, Horn $\mathrm{EM}$, Vieth $\mathrm{M}$, et al.: A randomised trial of endoscopic submucosal dissection versus endoscopic mucosal resection for early Barrett's neoplasia. Gut. 2017; 66(5): 783-93. PubMed Abstract | Publisher Full Text | Free Full Text

12. Vvan Hagen P, Hulshof MCCM, van Lanschot JJB, et al.: Preoperative Chemoradiotherapy for Esophageal or Junctional Cancer. N Engl J Med. 2012; 366(22): 2074-84.

PubMed Abstract | Publisher Full Text | Faculty Opinions Recommendation

13. C Shapiro J, van Lanschot JJB, Hulshof MCC, et al.: Neoadjuvant chemoradiotherapy plus surgery versus surgery alone for oesophageal or junctional cancer (CROSS): Long-term results of a randomised controlled trial. Lancet Oncol. 2015; 16(9): 1090-8.

PubMed Abstract | Publisher Full Text | Faculty Opinions Recommendation

14. Tepper J, Krasna MJ, Niedzwiecki D, et al.: Phase III trial of trimodality therapy with cisplatin, fluorouracil, radiotherapy, and surgery compared with surgery alone for esophageal cancer: CALGB 9781. J Clin Oncol. 2008; 26(7): 1086-92. PubMed Abstract | Publisher Full Text | Free Full Text
15. Mariette C, Dahan L, Mornex F, et al.: Surgery Alone Versus Chemoradiotherapy Followed by Surgery for Stage I and II Esophageal Cancer: Final Analysis of Randomized Controlled Phase III Trial FFCD 9901. JCO. 2014; 32(23): 2416-22.

PubMed Abstract | Publisher Full Text | Faculty Opinions Recommendation

16. Cunningham D, Allum WH, Stenning SP, et al.: Perioperative chemotherapy versus surgery alone for resectable gastroesophageal cancer. N Engl」 Med. 2006; 355(1): 11-20.

PubMed Abstract | Publisher Full Text | Faculty Opinions Recommendation

17. Elimova $E$, Janjigian $Y Y$, Mulcahy $M$, et al.: It Is Time to Stop Using Epirubicin to Treat Any Patient With Gastroesophageal Adenocarcinoma. JCO. 2017; 35(4): 475-7.

PubMed Abstract | Publisher Full Text

18. Al-Batran SE, Homann N, Pauligk C, et al.: Perioperative chemotherapy with fluorouracil plus leucovorin, oxaliplatin, and docetaxel versus fluorouracil or capecitabine plus cisplatin and epirubicin for locally advanced, resectable gastric or gastro-oesophageal junction adenocarcinoma (FLOT4): A randomised, phase 2/3 trial. Lancet. 2019; 393(10184): 1948-57.

PubMed Abstract | Publisher Full Text | Faculty Opinions Recommendation

19. NYchou M, Boige V, Pignon JP, et al.: Perioperative chemotherapy compared with surgery alone for resectable gastroesophageal adenocarcinoma: An FNCLCC and FFCD multicenter phase III trial. / Clin Oncol. 2011; 29(13): 1715-21.

PubMed Abstract | Publisher Full Text | Faculty Opinions Recommendation

20. Medical Research Council Oesophageal Cancer Working Group: Surgical resection with or without preoperative chemotherapy in oesophageal cancer: A randomised controlled trial. Lancet. 2002; 359(9319): 1727-33. PubMed Abstract | Publisher Full Text

21. Allum WH, Stenning SP, Bancewicz J, et al.: Long-term results of a randomized trial of surgery with or without preoperative chemotherapy in esophageal cancer. J Clin Oncol. 2009; 27(30): 5062-7.

PubMed Abstract | Publisher Full Text

22. Alderson $D$, Cunningham $D$, Nankivell $M$, et al:: Neoadjuvant cisplatin and fluorouracil versus epirubicin, cisplatin, and capecitabine followed by resection in patients with oesophageal adenocarcinoma (UK MRC OE05): An open-label, randomised phase 3 trial. Lancet Oncol. 2017; 18(9): 1249-60. PubMed Abstract | Publisher Full Text | Free Full Text

23. Cunningham D, Stenning SP, Smyth EC, et al.: Peri-operative chemotherapy with or without bevacizumab in operable oesophagogastric adenocarcinoma (UK Medical Research Council ST03): Primary analysis results of a multicentre, open-label, randomised phase 2-3 trial. Lancet results of a multicentre, Oncol. 2017; 18(3): 357-70.

PubMed Abstract | Publisher Full Text | Free Full Text | Faculty Opinions Recommendation

24. Harada K, Lopez A, Shanbhag N, et al.: Recent advances in the management of gastric adenocarcinoma patients. F1000Res. 2018; 7. PubMed Abstract | Publisher Full Text | Free Full Text

25. Bang YJ, van Cutsem E, Feyereislova A, et al.: Trastuzumab in combination with chemotherapy versus chemotherapy alone for treatment of HER2positive advanced gastric or gastro-oesophageal junction cancer (TOGA): A phase 3, open-label, randomised controlled trial. Lancet. 2010; 376(9742): 687-97.

PubMed Abstract | Publisher Full Text | Faculty Opinions Recommendation

26. Wilke $H$, Muro $K$, van Cutsem $E$, et al.: Ramucirumab plus paclitaxel versus placebo plus paclitaxel in patients with previously treated advanced gastric or gastro-oesophageal junction adenocarcinoma (RAINBOW): A double-blind, randomised phase 3 trial. Lancet Oncol. 2014; 15(11): 1224-35. PubMed Abstract | Publisher Full Text

27. Fuchs CS, Tomasek J, Yong CJ, et al.: Ramucirumab monotherapy for previously treated advanced gastric or gastro-oesophageal junction adenocarcinoma (REGARD): An international, randomised, multicentre, placebo-controlled, phase 3 trial. Lancet. 2014; 383(9911): 31-9.

PubMed Abstract | Publisher Full Text 
28. Kang JH, Lee SI, Lim DH, et al.: Salvage chemotherapy for pretreated gastric cancer: A randomized phase III trial comparing chemotherapy plus best supportive care with best supportive care alone. J Clin Oncol. 2012; 30(13): 1513-8. PubMed Abstract | Publisher Full Text

29. Le DT, Durham JN, Smith KN, et al.: Mismatch repair deficiency predicts response of solid tumors to PD-1 blockade. Science. 2017; 357(6349): 409-13. PubMed Abstract | Publisher Full Text | Free Full Text | Faculty Opinions Recommendation

30. Fuchs CS, Doi T, Jang RW, et al.: Safety and Efficacy of Pembrolizumab Monotherapy in Patients With Previously Treated Advanced Gastric and Gastroesophageal Junction Cancer: Phase 2 Clinical KEYNOTE-059 Trial. JAMA Oncol. 2018; 4(5): e180013.

PubMed Abstract | Publisher Full Text | Free Full Text | Faculty Opinions Recommendation

31. N Kang YK, Boku N, Satoh T, et al.: Nivolumab in patients with advanced gastric or gastro-oesophageal junction cancer refractory to or intolerant of at least two previous chemotherapy regimens (ONO-4538-12 ATTRACTION-2): A randomised, double-blind, placebo-controlled, phase 3 trial. Lancet. 2017; 390(10111): 2461-71.

PubMed Abstract | Publisher Full Text | Faculty Opinions Recommendation

32. Shitara K, Doi T, Dvorkin M, et al.: Trifluridine/tipiracil versus placebo in patients with heavily pretreated metastatic gastric cancer (TAGS): A randomised, double-blind, placebo-controlled, phase 3 trial. Lancet Oncol. 2018; 19(11): 1437-48.

PubMed Abstract | Publisher Full Text | Faculty Opinions Recommendation

33. Nentwich MF, von Loga K, Reeh M, et al.: Depth of submucosal tumor infiltration and its relevance in lymphatic metastasis formation for T1b squamous cell and adenocarcinomas of the esophagus. J Gastrointest Surg. 2014; 18(2): 242-9; discussion 249.

PubMed Abstract | Publisher Full Text

34. Kitagawa $Y$, Uno T, Oyama T, et al.: Esophageal cancer practice guidelines 2017 edited by the Japan Esophageal Society: Part 1. Esophagus. 2019; 16(1): $1-24$.

PubMed Abstract | Publisher Full Text | Free Full Text |

Faculty Opinions Recommendation

35. Kitagawa Y, Uno T, Oyama T, et al.: Esophageal cancer practice guideline 2017 edited by the Japan esophageal society: Part 2. Esophagus. 2019; 16(1): $25-43$.

PubMed Abstract | Publisher Full Text | Free Full Text |

Faculty Opinions Recommendation

36. Akutsu $Y$, Uesato $M$, Shuto $K$, et al.: The overall prevalence of metastasis in T1 esophageal squamous cell carcinoma: a retrospective analysis of 295 patients. Ann Surg. 2013; 257(6): 1032-8

PubMed Abstract | Publisher Full Text

37. Yamashina $T$, Ishihara $R$, Nagai $K$, et al.: Long-term outcome and metastatic risk after endoscopic resection of superficial esophageal squamous cell carcinoma. Am J Gastroenterol. 2013; 108(4): 544-51.

PubMed Abstract | Publisher Full Text

38. Minashi K, Nihei K, Mizusawa J, et al.: Efficacy of Endoscopic Resection and Selective Chemoradiotherapy for Stage I Esophageal Squamous Cell Carcinoma. Gastroenterology. 2019; 157(2): 382-390.e3.

PubMed Abstract | Publisher Full Text | Faculty Opinions Recommendation

39. Lordick F, Mariette C, Haustermans K, et al.: Oesophageal cancer: ESMO Clinical Practice Guidelines for diagnosis, treatment and follow-up. Ann Oncol. 2016; 27(Suppl 6): vi51-6.

PubMed Abstract | Publisher Full Text

40. Bedenne L, Michel P, Bouché O, et al.: Chemoradiation Followed by Surgery Compared With Chemoradiation Alone in Squamous Cancer of the Esophagus: FFCD 9102. JCO. 2007; 25(10): 1160-8. PubMed Abstract | Publisher Full Text

41. Ando $\mathrm{N}$, Kato $\mathrm{H}$, Igaki $\mathrm{H}$, et al:: A randomized trial comparing postoperative adjuvant chemotherapy with cisplatin and 5 -fluorouracil versus preoperative chemotherapy for localized advanced squamous cell carcinoma of the thoracic esophagus (JCOG9907). Ann Surg Oncol. 2012 19(1): 68-74.

PubMed Abstract | Publisher Full Text

42. Bleiberg $\mathrm{H}$, Conroy $\mathrm{T}$, Paillot $\mathrm{B}$, et al.: Randomised phase II study of cisplatin and 5-fluorouracil (5-FU) versus cisplatin alone in advanced squamous cel oesophageal cancer. Eur J Cancer. 1997; 33(8): 1216-20.

PubMed Abstract | Publisher Full Text

43. Lorenzen $\mathrm{S}$, Schuster $\mathrm{T}$, Porschen $\mathrm{R}$, et al.: Cetuximab plus cisplatin-5 fluorouracil versus cisplatin-5-fluorouracil alone in first-line metastatic squamous cell carcinoma of the esophagus: A randomized phase II study of the Arbeitsgemeinschaft Internistische Onkologie. Ann Oncol. 2009; 20(10): 1667-73.

PubMed Abstract | Publisher Full Text

44. Muro K, Hamaguchi T, Ohtsu A, et al:: A phase II study of single-agent docetaxel in patients with metastatic esophageal cancer. Ann Oncol. 2004; 15(6): 955-9.

PubMed Abstract | Publisher Full Text

45. Kato K, Tahara M, Hironaka S, et al.: A phase II study of paclitaxel by weekly 1-h infusion for advanced or recurrent esophageal cancer in patients who had previously received platinum-based chemotherapy. Cancer Chemother Pharmacol. 2011; 67(6): 1265-72.

PubMed Abstract | Publisher Full Text

46. Burkart C, Bokemeyer C, Klump B, et al.: A phase II trial of weekly irinotecan in cisplatin-refractory esophageal cancer. Anticancer Res. 2007; 27(4C): 2845-8.

PubMed Abstract

47. Kojima T, Muro K, Francois E, et al.: Pembrolizumab versus chemotherapy as second-line therapy for advanced esophageal cancer: Phase III KEYNOTE181 study. JCO. 2019; 37(15): 2 Publisher Full Text

48. Kato K, Cho BC, Takahashi M, et al.: Nivolumab versus chemotherapy in patients with advanced oesophageal squamous cell carcinoma refractory or intolerant to previous chemotherapy (ATTRACTION-3): A multicentre, randomised, open-label, phase 3 trial. The Lancet Oncology. 2019; 20(11): 1506-17.

PubMed Abstract | Publisher Full Text | Faculty Opinions Recommendation

49. Shah MA, Kojima T, Hochhauser D, et al.: Efficacy and Safety of Pembrolizumab for Heavily Pretreated Patients With Advanced, Metastatic Adenocarcinoma or Squamous Cell Carcinoma of the Esophagus: The Phase 2 KEYNOTE-180 Study. JAMA Oncol. 2019; 5(4): 546-50. PubMed Abstract | Publisher Full Text | Free Full Text | Faculty Opinions Recommendation

50. Chan KKW, Saluja R, Delos Santos K, et al.: Neoadjuvant treatments for locally advanced, resectable esophageal cancer: A network meta-analysis. Int J Cancer. 2018; 143(2): 430-7.

PubMed Abstract | Publisher Full Text | Faculty Opinions Recommendation

51. Swisher SG, Hofstetter W, Komaki R, et al.: Improved long-term outcome with chemoradiotherapy strategies in esophageal cancer. Ann Thorac Surg. 2010; 90(3): 892-8; discussion 898-9.

PubMed Abstract | Publisher Full Text

52. Stahl M, Walz MK, Stuschke M, et al.: Phase III comparison of preoperative chemotherapy compared with chemoradiotherapy in patients with locally advanced adenocarcinoma of the esophagogastric junction.J Clin Oncol. 2009; 27(6): 851-6.

PubMed Abstract | Publisher Full Text

53. Burmeister $\mathrm{BH}$, Thomas JM, Burmeister EA et al: Is concurrent radiation therapy required in patients receiving preoperative chemotherapy for adenocarcinoma of the oesophagus? A randomised phase II trial. Eur J Cancer. 2011; 47(3): 354-60.

PubMed Abstract | Publisher Full Text

54. Klevebro F, Alexandersson von Döbeln G, Wang N, et al.: A randomized clinical trial of neoadjuvant chemotherapy versus neoadjuvant chemoradiotherapy for cancer of the oesophagus or gastro-oesophageal junction. Ann Oncol. 2016; 27(4): 660-7.

PubMed Abstract | Publisher Full Text | Faculty Opinions Recommendation

55. Nakamura K, Kato K, Igaki $\mathrm{H}$, et al.: Three-arm phase III trial comparing cisplatin plus 5-FU (CF) versus docetaxel, cisplatin plus 5-FU (DCF) versus radiotherapy with CF (CF-RT) as preoperative therapy for locally advanced esophageal cancer (JCOG1109, NExT study). Jpn J Clin Oncol. 2013; 43(7): $752-5$.

PubMed Abstract | Publisher Full Text

56. Harada K, Wu CC, Wang X, et al.: Total Lesion Glycolysis Assessment Identifies a Patient Fraction With a High Cure Rate Among Esophageal Adenocarcinoma Patients Treated With Definitive Chemoradiation. Ann Surg. 2020; 272: 311-8.

PubMed Abstract | Publisher Full Text

57. Harada K, Wang X, Shimodaira Y, et al.: Early Metabolic Change after Induction Chemotherapy Predicts Histologic Response and Prognosis in Patients with Esophageal Cancer: Secondary Analysis of a Randomized Trial. Target Oncol. 2018; 13(1): 99-106. PubMed Abstract | Publisher Full Text | Free Full Text

58. Swisher SG, Moughan J, Komaki RU, et al.: Final Results of NRG Oncology RTOG 0246: An Organ-Preserving Selective Resection Strategy in Esophageal Cancer Patients Treated with Definitive Chemoradiation. J Thorac Oncol. 2017; 12(2): 368-74.

PubMed Abstract | Publisher Full Text | Free Full Text

59. Noordman BJ, Spaander MCW, Valkema R, et al.: Detection of residual disease after neoadjuvant chemoradiotherapy for oesophageal cancer (preSANO): A prospective multicentre, diagnostic cohort study. Lancet Oncol. 2018; 19(7): 965-74.

PubMed Abstract | Publisher Full Text | Faculty Opinions Recommendation

60. Noordman BJ, Wijnhoven BPL, Lagarde SM, et al.: Neoadjuvant chemoradiotherapy plus surgery versus active surveillance for oesophageal cancer: A stepped-wedge cluster randomised trial. $B M C$ Cancer. 2018; 18(1): 142

PubMed Abstract | Publisher Full Text | Free Full Text

61. Kato K, Igaki $\mathrm{H}$, Ito $\mathrm{Y}$, et al.: Parallel-group controlled trial of esophagectomy versus chemoradiotherapy in patients with clinical stage I esophageal carcinoma (JCOG0502). JCO. 2019; 37(4_suppl): 7.

Publisher Full Text 
62. Mitchell KG, Nelson DB, Corsini EM, et al.: Morbidity following salvage esophagectomy for squamous cell carcinoma: The MD Anderson experience. Dis Esophagus. 2020; 33(3): doz067. PubMed Abstract | Publisher Full Text

63. Nomura M, Kato K, Ando N, et al.: Comparison between neoadjuvant chemotherapy followed by surgery and definitive chemoradiotherapy for overall survival in patients with clinical Stage II/III esophageal squamous cell carcinoma (JCOG1406-A). Jpn J Clin Oncol. 2017; 47(6): 480-6. PubMed Abstract | Publisher Full Text

64. Comprehensive molecular characterization of gastric adenocarcinoma. Nature. 2014; 513(7517): 202-9.

PubMed Abstract | Publisher Full Text | Free Full Text

Faculty Opinions Recommendation

65. Wang R, Song S, Harada K, et al.: Multiplex profiling of peritoneal metastases from gastric adenocarcinoma identified novel targets and molecular subtypes that predict treatment response. Gut. 2019; 69(1): 18-31. PubMed Abstract | Publisher Full Text | Free Full Text

66. Reeh M, Effenberger KE, Koenig AM, et al.: Circulating Tumor Cells as a Biomarker for Preoperative Prognostic Staging in Patients With Esophageal Cancer. Ann Surg. 2015; 261(6): 1124-30.

PubMed Abstract | Publisher Full Text | Faculty Opinions Recommendation

67. Alix-Panabières C, Pantel K: Clinical Applications of Circulating Tumor Cells and Circulating Tumor DNA as Liquid Biopsy. Cancer Discov. 2016; 6(5): 479-91. PubMed Abstract | Publisher Full Text | Faculty Opinions Recommendation

68. Chaudhuri AA, Binkley MS, Osmundson EC, et al.: Predicting Radiotherapy Responses and Treatment Outcomes Through Analysis of Circulating Tumor DNA. Semin Radiat Oncol. 2015; 25(4): 305-12.

PubMed Abstract | Publisher Full Text | Free Full Text

Faculty Opinions Recommendation 


\section{Open Peer Review}

\section{Current Peer Review Status:}

\section{Editorial Note on the Review Process}

Faculty Reviews are review articles written by the prestigious Members of Faculty Opinions. The articles are commissioned and peer reviewed before publication to ensure that the final, published version is comprehensive and accessible. The reviewers who approved the final version are listed with their names and affiliations.

\section{The reviewers who approved this article are:}

\section{Version 1}

\section{James P. Dolan}

Division of Gastrointestinal and General Surgery, Department of Surgery, Oregon Health and Science University, Portland, OR, USA

Competing Interests: No competing interests were disclosed.

\section{Daniela Molena}

Department of Surgery, Memorial Sloan Kettering Cancer Center, New York, NY, USA

Competing Interests: No competing interests were disclosed.

\section{Rebecca K. S. Wong}

Princess Margaret Cancer Centre, University Health Network, University of Toronto, Toronto, ON, Canada

Competing Interests: No competing interests were disclosed.

The benefits of publishing with F1000Research:

- Your article is published within days, with no editorial bias

- You can publish traditional articles, null/negative results, case reports, data notes and more

- The peer review process is transparent and collaborative

- Your article is indexed in PubMed after passing peer review

- Dedicated customer support at every stage

For pre-submission enquiries, contact research@f1000.com 